\title{
Milena Śliwińska*
}

\section{Szkic do portretu Artura Hutnikiewicza. O dedykacjach w książkach z biblioteki Profesora}

DOI: http://dx.doi.org/10.12775/LC.2016.062

1.

wyczaj wpisywania w książce dowodów uznania czy próśb o lekturę i przyjęcie publikacji, sięgający tradycji antycznego listu otwartego ${ }^{1}$, rozwijał się w okresie staropolskim ${ }^{2}$, kontynuowany był także w oświeceniu oraz w XIX ${ }^{3}$ i XX wieku. Obok dedykacji rękopiśmiennych od XV wieku istniały dedykacje drukowane $e^{4}$ oraz listy dedykacyjne ${ }^{5}$. Celem dedykacji rękopiśmiennych było wyrażenie szacunku, czci, wdzięczności, nawiązanie bądź podtrzymanie relacji i upamiętnienie znajomości. Dedykacje rękopiśmienne występują w niezliczonej liczbie form: od lapidarnych formuł po teksty, które wyłamują się z typowej

\footnotetext{
* Doktor nauk humanistycznych, kierownik biblioteki Wydziału Filologicznego Uniwersytetu Mikołaja Kopernika w Toruniu. E-mail: milena.sliwinska@umk.pl.

1 E. Zemszał, O dedykacjach rękopiśmiennych z księgozbioru Marii i Jerzego Kuncewiczów, „Folia Bibliologica” 2010, vol. 52, s. 49.

2 A. Czekajewska, O listach dedykacyjnych w polskiej ksiażce XVI w., „Roczniki Biblioteczne ” 1962 z. 1/2, s. 21-55; B. Mazurkowa, Literacka rama wydawnicza dziel Franciszka Dionizego Kniaźnina (na tle porównawczym), Katowice 1993, s. 18; eadem, Na ziemskich i niebieskich szlakach. Studia o poezji Franciszka Zabłockiego i Franciszka Dionizego Kniaźnina, Katowice 2008, s. 85-109.

3 H. Markiewicz, Jak się dawniej dedykacje pisaty, „Teksty Drugie” 2002, z. 4, s. 216-229.

4 Por. M. Winnicka, Dedykacje rękopiśmienne $w$ ksiażkach z fragmentu księgozbioru domowego poetki Marianny Bocian, „Annales Academiae Paedagogicae Cracoviensis” 2008, Folia 61 „Studia ad Bibliothecarum Scientiam Pertinentia”, VI, s. 79.

5 R. Ocieczek, O listach dedykacyjnych literatów polskich XVII wieku (Wprowadzenie do badań), „Ruch Literacki” 1977, z. 6, s. 447-459; Eadem, Staworodne wizerunki. O wierszowanych listach dedykacyjnych z XVII wieku, Katowice 1982; A. Czekajewska, Kultura umystowa Polski XVI w. w świetle listów dedykacyjnych, „Studia i Materiały z Dziejów Nauki Polskiej” 1965, seria A, z. 7, s. 55-68.
} 
krótkiej i schematycznej kompozycji ${ }^{6}$ i często przybierają nawet kształt literacki. Te zwięzłe nie wykraczają poza sferę konwencji. Rozbudowane posiadają motta, osobiste odwołania, elementy wspomnień, zwroty charakteryzujące i omawiające darowaną pozycję. Określa je pomysłowość ofiarującego książkę, autora, tłumacza, opracowującego oraz to, kto jest ich adresatem.

Te małe formy wypowiedzi umieszczane przez autora na pojedynczych egzemplarzach są indywidualnie przeznaczone dla odbiorcy. Odróżnia je to od dedykacji drukowanej, utrwalonej na wszystkich egzemplarzach książki, skierowanej do jednego adresata, ofiarowującej samo dzieło. Dedykacja rękopiśmienna pozwala ofiarować książkę jako przedmiot i umożliwia powtarzalność tego aktu bez utraty oryginalności ${ }^{7}$.

Formuły wyrażające szacunek i uznanie, wpisywane na początku publikacji, mogą być źródłem do studiów nad społecznym postrzeganiem osoby obdarowywanej, adresata wpisów. Badanie dedykacji rękopiśmiennych znajdujących się w księgozbiorach naukowców, literatów, bibliofilów stawia obdarowywanych w nowym świetle. Właścicieli księgozbioru pokazuje od strony prywatnej. Dedykacje są świadectwem kontaktów naukowych, relacji obdarowywanego z kolegami, koleżankami, współpracownikami czy uczniami i składają się na wizerunek adresata. Wykorzystywane są również jako metaliterackie opowieści o dziele, w lapidarny sposób opisujące treść i charakter danej publikacji. Wreszcie dedykacje rękopiśmienne, przez swoją intymność (nie ma w nich drugiego odbiorcy, czytelnika, który czyta dedykację wydrukowaną w publikowanej książce) przekazują więcej informacji, stając się zwierzeniami biograficznymi i autobiograficznymi ${ }^{8}$.

Artykuł jest próbą zrekonstruowania portretu Artura Hutnikiewicza i powstał dzięki analizie dedykacji rękopiśmiennych w publikacjach znajdujących się w prywatnym księgozbiorze autora Młodej Polski. Dedykacje stanowią dla tej rekonstrukcji swoiste źródło informacji o Hutnikiewiczu, o jego działalności naukowej, dydaktycznej, o przeszłości, pochodzeniu i o tym, jak odbierany był przez ludzi, którzy go otaczali.

$\mathrm{Na}$ tle wpisów Hutnikiewicz jawi się jako osoba darzona ogromnym szacunkiem, o uznanym dorobku naukowym, jako mistrz i autorytet dla studentów polonistyki. Wpisy są także świadectwem wielkiego uznania, jakim cieszył się Profesor w środowisku literaturoznawców. Był osobą, do której młodsi koledzy i adepci nauki o literaturze przychodzili po pomoc i wsparcie naukowe, z której opiniami liczyli się i brali je pod uwagę w swojej pracy. Obraz wyłaniający się z dedykacji odsłania także Profesora jako lwowianina, zawsze pamiętającego o opuszczonym przez siebie mieście, oraz jako serdecznego kolegę i przyjaciela, a zgromadzony księgozbiór dowodzi jego szerokich zainteresowań i pasji bibliofilskiej. Księgozbiór Artura Hutnikiewicza liczy ponad 5 tys. wolumenów, które obecnie znajdują się w Bibliotece Collegium Maius Wydziału Filologicznego Uniwersytetu Mikołaja Kopernika w Toruniu. Wśród literatury pięknej, książek naukowych, albumów, dotyczących m.in. Lwowa czy historii sztuki, znalazło się 376 publikacji zawierających dedykacje

${ }^{6}$ Por. M. Krauz, Profesor, Mistrz, Przyjaciel, Kolega - o dedykacjach poświęconych Profesorowi Piotrowi Żbikowskiemu, „Słowo. Studia językoznawcze” 2014, z. 5, s. 133; eadem, „Z wyrazami prawdziwej przyjaźni” - o strukturze i stylu dedykacji autorskich w księgozbiorze Floriana Śmiei, „Zeszyty Naukowe Uniwersytetu Rzeszowskiego. Seria Filologiczna. Historia Literatury" 2011, z. 70, s. 337-354.

7 M. Winnicka, op. cit., s. 82

8 Zob. R. Ocieczek, O listach dedykacyjnych literatów polskich XVII wieku [... ], s. 456. 
rękopiśmienne, składane przez autorów i redaktorów dzieł. Najwcześniejsza dedykacja pochodzi z 1922 roku i wpisana została przez matkę Profesora.

\section{2.}

Wiele z dedykacji jest świadectwem uznania, jakim Hutnikiewicz cieszył się jako mistrz, nauczyciel, wykładowca, mentor, co poświadcza wpis Krystyny Jóźwiak ${ }^{9}$, która swoją książkę ofiarowała: mojemu autorytetowi $z$ czasów studenckich $i$ nie tylko $[\ldots]^{10}$. Hutnikiewicza jako swojego mistrza określiła w dedykacjach także m.in. Krystyna Jakowska, która wpis rozpoczęła słowami: Bardzo Drogiemu Mistrzowi [...], a następnie skromnie opisała darowaną publikację jako $[\ldots]$ produkt uporu $i$ wytrwałości $[\ldots]^{11}$. W podobnym tonie $\mathrm{w}$ dedykacji wyraził się Janusz Kryszak, który publikację Poezja ziemi. Międzywojenna twórczość poetycka Mariana Czuchnowskiego ofiarował Mistrzowi mojej edukacji $[\ldots]^{12}$.

Literaturoznawcy wychowani pod skrzydłami Profesora wspominali w dedykacjach jego zajęcia. Ćwiczenia z poetyki przywoływała Jakowska, która w książce Cykl literacki w Polsce napisała tak: Kochanemu, Drogiemu Panu Profesorowi na pamiątkę wspaniatych ćwiczeń z poetyki $[\ldots]^{13}$. Echo prowadzonych konwersatoriów znalazło się również $\mathrm{w}$ dedykacji napisanej przez Andrzeja Stoffa, który wyraził szacunek i uznanie dla Profesora jako nauczyciela poetyki ${ }^{14}$. Edukacyjne spotkania z Profesorem wracały także w dedykacji Aleksandra Madydy, który swoją książkę opatrzył adnotacją: [... ] pierwszemu nauczycielowi prawdziwej historii i teorii literatury z najgłębsza wdzięcznością ${ }^{15}$. Profesorskie wykłady stały się tematem dedykacji Leokadii Pośpiechowej: [... ] z wyrazami wdzięczności za życzliwość i za wszelkie wzruszenia, których doznałam słuchają Jego prelekcji ${ }^{16}$. Natomiast Lidia Kuchtówna napisała z sentymentem: Panu Profesorowi [...] z wyrazami wielkiego szacunku i z podziękowaniem za wykłady z modernizmu, których stuchałam jako studentka ${ }^{17}$. Prace przygotowywane na seminariach prowadzonych przez Profesora znajdowały czasem wyjątkowych czytelników, czego dowodem jest dedykacja Kazimierza Wierzyńskiego wpisana w Tkance ziemi przesłanej Hutnikiewiczowi w listopadzie 1963 roku. Wierzyński napisał: Drogi Panie Profesorze! Czy to Panu mam do zawdzięczenia, że ktoś się o mnie upomniat? Kto to jest p. Palacz? Przesytam ostatnia moją książę i zatączam serdeczne pozdrowienia i najlepsze myśli $i^{18}$. Jerzy Palacz w 1962 roku uzyskał magisterium na podstawie pracy pt. Pierwszy okres twórczości K. Wierzyńskiego. Promotorem był Artur Hutnikiewicz ${ }^{19}$. Praca znalazła się w rękach Wierzyńskiego, być może przesłana przez Profesora.

\footnotetext{
9 Poetka, polonistka, uczennica Profesora Hutnikiewicza, ur. 1938. Por. Krystyna Jóźwiak, http://www.baza-nazwisk.de/ suche.php?data=25415 (dostęp 28.11.2016).

10 K. Karpińska-Jóźwiak, Nie wiem, Toruń 1982.

11 K. Jakowska, Z dziejów ekspresjonizmu w Polsce. Wokót „Soli ziemi”, Wrocław 1977.

12 J. Kryszak, Poezja ziemi. Międzywojenna twórczość poetycka Mariana Czuchnowskiego, Warszawa 1984.

13 Cykl literacki w Polsce, pod red. K. Jakowskiej, B. Olech i K. Sokołowskiej, Białystok 2001.

14 A. Stoff, Formy wypowiedzi dramatycznej, Toruń 1985.

15 A. Madyda, Zygmunt Haupt. Życie i twórczość literacka, Toruń 1998.

16 L. Pośpiechowa, Twórczość literacka Włodzimierza Tetmajera, Wrocław 1974.

17 L. Kuchtówna, Irena Solska, Warszawa 1980.

18 K. Wierzyński, Tkanka ziemi, Londyn 1960.

19 Katedra Literatury Polskiej Uniwersytetu Toruńskiego, „Biuletyn Polonistyczny” 1963, 6/17, s. 47.
} 
up Orhar Mutuibieaniez To24a'

univerviterim. Moperuita

Srovi Pacei kofososp!

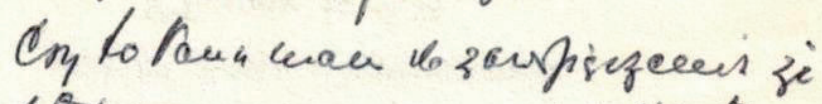

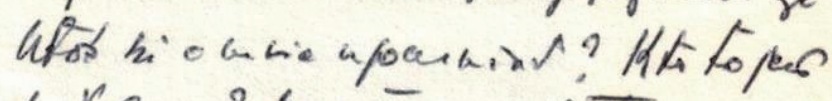

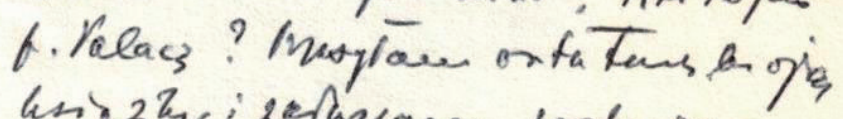

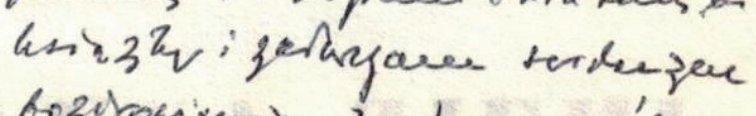

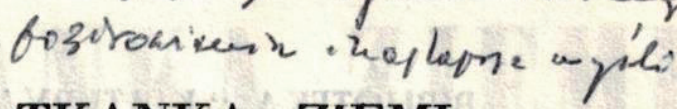
TKANKA ZIEMI

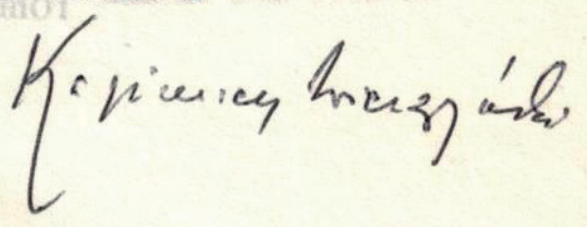

Mory Oon, lestapad 4963.

Eleuburif $7 z, 9.4$.

BIBLIOTEKA ARTURA HUTNIKIEWICZA

Autograf dedykacji Kazimierza Wierzyńskiego, fot. Milena Śliwińska 
Obok wpisów, które przywoływały zajęcia z Hutnikiewiczem lub były swoistym dowodem ich znaczenia, znalazły się dedykacje, w których uczniowie wyrażali uznanie i wdzięczność za lata studiów i nauki.

$\mathrm{Na}$ zbiór dedykacji zawierających słowa podziękowania i docenienie Profesora Hutnikiewicza jako nauczyciela składają się wpisy Kryszaka, który swoje dedykacje podpisywał jako „Uczeń” ${ }^{20}$. Publikację Rzeczywistość trzecia zadedykował Mistrzowi wpisując w niej tekst: [...] jak zawsze z wdzięcznościa za lata terminowania $[\ldots]^{21}$. Książki z dedykacjami od Kryszaka stanowią liczny zbiór. Znaleźć w nich można podziękowania za nauczycielska pomoc i troskę $e^{22}$ oraz za stworzenie możliwości do pracy twórczej i naukowej, o czym napisał w 1979 roku w dedykacji poprzedzonej mottem: „To, co chciałem o sobie rzec, / / Powiedziałem o pokoleniu, / Które do dna sięgało cieniów, / A na oślep musiało biec”. Te stowa Jerzego Zagórskiego winny być mottem tej książi i właśnie za stworzenie mi warunków do napisania tak osobistej książki chciałbym goraco podziękować Panu, Panie Profesorze. Panu Profesorowi Arturowi Hutnikiewiczowi z wdzięcznościa i szacunkiem ${ }^{23}$.

Dedykacje Wojciecha Gutowskiego potwierdzały wizerunek Hutnikiewicza jako Mistrza. W książce Pasje wyobraźni. Szkice o literaturze romantyzmu i Młodej Polski autor napisal: Wielce Czcigodnemu Panu Profesorowi [... ] z wyrazami szczerej wdzięczności ofiarowuję tę książeczkę - pokłosie lat terminowania w kręgu inspirujacego Mistrza ${ }^{24}$. Także Ryszard Karwacki swoją dedykacją wpisał się w konwencję podziękowań dla Nauczyciela łącząc ją z osobliwą charakterystyką Profesora: Wielce Szanownemu Panu Profesorowi [... ] Z głębokim szacunkiem dla Jego Osoby Spolegliwej oraz podziękowaniem za ofiarowana mi życzliwość i lata udzielanych nauk ${ }^{25}$. Wdzięczność za edukację polonistyczną ${ }^{26}$ wyraził także Jan Bełkot. Dedykację w duchu podziękowań wpisał w swojej książce również Janusz Skuczyński: Dziękuję za petne życzliwości wprowadzenie mnie w wielki coraz większy polonistyczny świat ${ }^{27}$. Natomiast w publikacji Odmiany form dramatycznych $w$ okresie romantyzmu. Stowacki Mickiewicz - Krasiński kolejny raz autor zawarł podziękowania dla Nauczyciela za wprowadzenie w świat literatury i teatru ${ }^{28}$.

O roli Hutnikiewicza jako przewodnika w świecie nauki i literatury świadczy także wpis Kazimierza Świegockiego, który w tomiku Morze utracone $e^{29}$ tak pisał: Czcigodnemu Panu Profesorowi [...], którego dzieła pomagaty mi w czasach studenckich i pomagają do dziś lepiej zrozumieć literaturę i człowieka - użytkownika słowa w osiemdziesiątym roku Jego uro$d z i n$. Wpis ten czcił ponadto jubileusz Profesora. Także Stefan Frankiewicz ${ }^{30}$, obdarowując Hutnikiewicza wydaniem poezji Jerzego Lieberta we własnym wyborze, zawarł podziękowanie $[. .$.$] za wszystko, co byto, a co pozwala mi dziś pisać3 { }^{31}$ Włodzimierz Kowalewski

\footnotetext{
20 J. Kryszak, Mały wybór, Olsztyn 1992; idem, Urojona perspektywa. Szkice literackie, Łódź 1981.

21 Idem, Rzeczywistość trzecia, Bydgoszcz 1997.

22 Idem, Katastrofizm ocalajacy. Z problematyki poezji tzw. „Drugiej Awangardy”, Bydgoszcz 1985.

23 Idem, Katastrofizm ocalajacy. Z problematyki poezji tzw. „Drugiej Awangardy”, Warszawa 1978.

24 W. Gutowski, Pasje wyobraźni. Szkice o literaturze romantyzmu i Młodej Polski, Toruń 1992.

25 R. Karwacki, Temat morski. O prozie fabularnej dwudziestolecia międzywojennego, Gdańsk 1975.

26 J. Bełkot, Rozpad i trwanie. O prozie Tadeusza Berezy, Łódź 1980.

27 J. Skuczyński, O przestrzeni teatralnej w dramatach Juliusza Stowackiego, Warszawa 1986.

28 Idem, Odmiany form dramatycznych w okresie romantyzmu. Stowacki - Mickiewicz - Krasiński, Toruń 1993.

29 K. Świegocki, Morze utracone, Warszawa 1995.

30 Historyk literatury, redaktor, uczeń prof. Konrada Górskiego, ur. 1940. Por. Stefan Frankiewicz, http://www.wiez.pl/ Stefan-Frankiewicz;s,autorzy,id,189 (dostęp 28.11.2016).

31 J. Liebert, Poezje wybrane, wyboru dokonał i wstępem opatrzył Stefan Frankiewicz, Warszawa 1973.
} 
w literackiej dedykacji złożonej w zbiorze opowiadań wyraził podziękowanie, potwierdzając opinię o Hutnikiewiczu jako charyzmatycznym wykładowcy, autorytecie, a także jako człowieku zaangażowanym w los osób, z którymi się spotykał. Autor ofiarował Profesorowi książkę [... ] w podziękowaniu za wszystko, co uczynił dla ukazania się tej książki, za opinie podtrzymujące u autora wiarę we wtasne możliwości, za wykłady przywodzące do wniosku, że potęga dobra tkwi w pięknie, za wspaniate książi będące fascynująca opowieścia o ludziach $i$ duchu literatury, a nie układanka szarych, naukowych terminów ${ }^{32}$. To zaangażowanie Profesora w naukowe życie uczniów czy osób, z którymi współpracował, potwierdza także dedykacja Andrzeja Z. Makowieckiego, który dziękował Hutnikiewiczowi za naukowy patronat w kolejnych etapach mojego rozwoju naukowego i podziwem wobec Jego kolejnych, wspaniałych ksiązek ${ }^{33}$.

Wśród dedykacji, w których autorzy podkreślali wdzięczność za opiekę naukową i zainteresowanie, znajduje się również wpis w książce Jerzego Speiny, brzmiący: Wielce Szanownemu i Drogiemu Panu Profesorowi [... ] z prośba o przyjęcie wyrazów wdzięczności za szczera i nieustanną troskę o losy tej książki i jej autora ${ }^{34}$. Natomiast Bogdan Burdziej w $1991 \mathrm{r}$. w podzięce za pomoc naukową ofiarował Profesorowi rozprawę doktorską, w której wpisał dedykację: Panu Profesorowi Artur Hutnikiewiczowi $Z$ wdzięcznością za wieloletnia opiekę naukowa i życzliwośćs.

Profesor Hutnikiewicz, mistrz młodych literaturoznawców, zdobywających pod jego opieką polonistyczne szlify, był także czytelnikiem ich publikacji, a jak wiemy z dedykacji np. profesora Speiny, troszczył się również o losy wydawnicze prac publikowanych m.in. w Towarzystwie Naukowym w Toruniu ${ }^{36}$. Po lekturze tekstów wyrażał krytyczne uwagi i dzielił się spostrzeżeniami, co pozwalało je poprawić i udoskonalić. Był także recenzentem monografii, o czym wspominała np. Maria Januszewicz: Kochanemu Panu Profesorowi [... ] Recenzentowi tej ksiązki w podziękowaniu za petna życzliwości akceptację i naukowa opiekę $w U M K w$ Toruniu $[\ldots]^{37}$.

\section{3.}

Wiele osób ofiarowywało Profesorowi książki z dedykacjami zawierającymi prośby o lekturę, recenzję, krytyczne uwagi i łaskawe przyjęcie publikacji, o co np. prosił Stanisław Stabryła w dedykacji wpisanej do angielskiej wersji swego doktoratu ${ }^{38}$. Wśród wpisów, których autorzy prosili Hutnikiewicza o lekturę, znalazły się adnotacje z prośba o krytyczna lekturę autorstwa m.in. Wojciecha Gutowskiego ${ }^{39}$. W podobnym tonie dedykację wpisał

\footnotetext{
32 W. Kowalewski, Cztery opowiadania o śmierci, Bydgoszcz 1993.

33 A.Z. Makowiecki, Literatura Młodej Polski. Podręcznik [... ], Warszawa 1994.

34 J. Speina, Powieści Stanistawa Ignacego Witkiewicza. Geneza i struktura, Toruń 1965.

35 B. Burdziej, Inny świat ludzkiej nadziei. Szkice Adama Szymańskiego na tle literatury zsytkowej, Toruń 1991.

36 Artur Hutnikiewicz był redaktorem naczelnym Wydawnictw TNT w Toruniu od 1960 roku.

37 M. Januszewicz, Malowany dramat. O związkach literatury z malarstwem $w$ „Weselu” Stanisława Wyspiańskiego, Zielona Góra 1994.

38 S. Stabryła, Latin tragedy in Virgil's poetry, Wrocław 1970.

39 T. Miciński, Poematy proza, oprac. W. Gutowski, Kraków 1985.
} 
również Mieczysław Łojek, który prosił o przyjęcie i ocenę książki poświęconej Ignacemu Chrzanowskiemu ${ }^{40}$.

Podziękowania za wszelkie uwagi znaleźć można w dedykacjach Krzysztofa Ćwiklińskiego, który pisał: Drogi Panie Profesorze, proszę o łaskawe przyjęcie tej ksiażki, która dzięki Pańskim uwagom uzyskała swój ostateczny (mam nadzieję, szlachetny) szlif ${ }^{41}$. Również Zygmunt Dokurno ${ }^{42}$ przekazał Hutnikiewiczowi publikację, w której wspomniał o pomocnych wskazówkach, jakie dostał od Profesora i o wdzięczności za nie: [...] z serdecznym podziękowaniem za poważne ustosunkowanie się do mojej pracy, wyrażające się w krytycznych uwagach, które pozwolity mi usuną́ fragmenty niedostatecznie przemyślane ${ }^{43}$. Także publikacja książki Grzegorza Gazdy Futuryzm w Polsce nie obyła się bez konsultacji z Hutnikiewiczem, o czym autor tak napisał w dedykacji: [... ] Panu Profesorowi, [... ] jednemu z pierwszych krytycznych i życzliwych czytelników tej pracy, z wyrazami głębokiej wdzięczności za cenne uwagi, dzięki którym ten tekst zyskat bardzo wiele ${ }^{44}$.

Również Jerzy Starnawski znalazł się w gronie naukowców, których prace recenzował Hutnikiewicz. W publikacji Sylwetki lwowskich historyków literatury zamieścił podziękowanie za recenzję wydawniczą ${ }^{45}$.

Wśród książek zawierających klasyczne dedykacje z prośbą o przyjęcie publikacji znaleźć można w księgozbiorze Profesora m.in. wpisy: Henryka Markiewicza: Szanownego Pana Profesora Artura Hutnikiewicza o przyjęcie tej pracy prosi Autor ${ }^{46}$, Stanisława Burkota: $Z$ prośba o taskawe i pobtażliwe przyjęcie ${ }^{47}$ czy Kazimierza Wyki: Prof. Artur Hutnikiewicz zechce łaskawie przyjać wraz z bukietem najlepszych i przychylnych życzeñ ${ }^{48}$. Właśnie te ostatnie dedykacje potwierdzają uznanie, jakim cieszył się Profesor Hutnikiewicz wśród literaturoznawców z innych ośrodków naukowych.

\section{4.}

Do wizerunku mistrza, nauczyciela, czytelnika i krytyka należy dodać także obraz wybitnego naukowca, jaki również wyłania się z dedykacji w ofiarowanych książkach. Znaleźć można wzmianki o współpracy, o publikacjach Profesora, o jego zaangażowaniu w pracę naukową, o znaczeniu jego dokonań dla literaturoznawstwa polskiego czy o humanistycznym wkładzie $w$ dorobek nauki polskiej ${ }^{49}$, o czym wspomniał we wpisie Dariusz T. Lebioda. W publikacji Biografie pisarzy w nauczaniu literatury zamieszczono dedykację, której autor odniósł się do osiągnięć Profesora swoją pracę dedykując: wybitnemu badaczowi dziejów literatury

40 M. Łojek, Ignacy Chrzanowski jako badacz literatury i profesor, cz. 1, Bydgoszcz 1991.

41 K. Ćwikliński, Idea i rzecz, Londyn 1987.

${ }^{42}$ Historyk literatury, doktor, ur. 1928 - zm. 2009. Związany w UMK w Toruniu. Por. Dokurno Zygmunt, [hasło w: ]

Katalog Nukat, http://katalog.nukat.edu.pl/ (dostęp 28.11.2016).

43 Z. Dokurno, Kompozycja utworów lirycznych C.K. Norwida (do roku 1852), Toruń 1965.

44 G. Gazda, Futuryzm w Polsce, Wrocław 1974.

45 J. Starnawski, Sylwetki lwowskich historyków literatury, Łódź 1997.

46 H. Markiewicz, „Ludzie bezdomni” Stefana Żeromskiego, Warszawa 1963.

47 S. Burkot, Marchott na Parnasie. Szkice literackie, Warszawa 1980.

48 W. Wyka, Pan Tadeusz. Studia o poemacie, Warszawa 1963.

49 D.T. Lebioda, Krew Jednorożca, Bydgoszcz 1997. 
ojczystej ${ }^{50}$. Wśród dedykacji, które mówiły o naukowym uznaniu dla Hutnikiewicza, odnaleźć można następujący wpis Jana Józefa Lipskiego: Szanownemu Panu Profesorowi [... ] znakomitemu znawcy epoki i Poety z wyrazami szacunku i uściskiem dtoni przesyła swe nowe Kasprowiczianum $^{51}$. Dla badaczy Profesor był także przykładem, o czym można przeczytać w dedykacji Adeli Pryszczewskiej, która tak odnosiła się do Hutnikiewicza: Temu, którego wiedza i człowieczeństwo są dla mnie niedościgtym wzorem, Najznakomitszemu Uczonemu i Znawcy Literatury, Ukochanemu Profesorowi Arturowi Hutnikiewiczowi w najczulszym hołdzie i z dozgonna wdzięcznością ${ }^{52}$. Również Makowiecki w dedykacji zaakcentował osiągnięcia i działalność naukową. Autor Młodopolskiego portretu artysty w swoim wpisie podziękował Profesorowi za recenzję jego książki: [...] z wyrazami wdzięczności za łaskawa recenzję tej ksiażki i szacunku wobec Jego prac naukowych o ludziach i epoce Młodej Polski ${ }^{53}$. Natomiast Czesław Zgorzelski w dedykacji wypowiadał uznanie dla przedstawionego przez Hutnikiewicza referatu: Drogiemu Koledze, Panu Profesorowi Arturowi Hutnikiewiczowi $z$ gratulacjami $z$ powodu pięknego i społecznie bardzo cennego referatu ${ }^{54}$. Wpis ten złożył w 1978 roku w książce Od oświecenia ku romantyzmowi i wspótczesności.

Szczególne miejsce wśród dedykacji zajmują wpisy profesora Konrada Górskiego, który darował Hutnikiewiczowi każdą swoją nową publikację, zawsze z bardzo życzliwą adnotacją. W dedykacjach Górskiego Hutnikiewicz określony był jako „Kochany i Drogi Kolega”, wyjątkiem jest wpis w książce Mickiewicz. Artyzm i język, gdzie Górski grzecznościowo dystansuje się zwracając się do Hutnikiewicza per „Pan”. Dedykacja nie traci jednak swego serdecznego, ciepłego i przyjaznego charakteru: Kochanemu i Drogiemu Panu Prof. Arturowi Hutnikiewiczowi z wyrami mojej niezmiennej przyjaźni, podziwu dla Jego pracy naukowej i dydaktycznej, a wreszcie wdzięczności za Jego przemówienie na jubileuszu mojego 80-lecia ${ }^{55}$. Profesor Górski ze szczególnym poważaniem pisał o działalności Hutnikiewicza w Towarzystwie Naukowym w Toruniu, o której wspomniał w dedykacji zamieszczonej w czwartym tomie dzieł Mickiewicza: Wielce Szanownemu i Drogiemu Koledze Profesorowi Dr. Arturowi Hutnikiewiczowi z wyrazami szczerego uznania dla Jego pracy naukowej i dziatalności $w$ Towarzystwie Naukowym $w$ Toruniu ${ }^{56}$.

Profesor Górski nie był jedynym przedstawicielem starszego pokolenia wybitnych literaturoznawców, którzy z szacunkiem i uznaniem zwracali się do Profesora w dedykacjach. W 1956 roku Juliusz Kleiner ofiarował Hutnikiewiczowi książkę. Studia z zakresu teorii literatury zawierały wpis: Wielce Szanownego Pana Kolegę Doc. Dr. Artura Hutnikiewicza o przyjęcie tej książki prosi łączac serdeczne uściski dłoni ${ }^{57}$. Dedykacja Jadwigi Czachowskiej zamieszczona w książce pt. Rozwój bibliografii literackiej w Polsce świadczy o głębokim zaufaniu, jakim autorka darzyła Profesora. Książka została podarowana Hutnikiewiczowi w 1980 roku z dedykacją: Szanownemu i Drogiemu Panu Profesorowi [... ] - z prośba o przyjęcie tej ksiażki, w której wiele o działaniach bibliograficznych lwowskiej polonistyki ${ }^{58}$. Stronę

\footnotetext{
50 M. Łojek, Biografie pisarzy w nauczaniu literatury, Warszawa 1985.

51 J. Kasprowicz, Wybór poezji, oprac. J.J. Lipski, Wrocław 1973.

52 A. Pryszczewska-Kozołub, Pisarstwo Poli Gojawiczyńskiej, Warszawa 1980.

53 A.Z. Makowiecki, Młodopolski portret artysty, Warszawa 1971.

54 C. Zgorzelski, Od oświecenia ku romantyzmowi i wspótczesności, Kraków 1978.

55 K. Górski, Mickiewicz. Artyzm i język, Warszaw 1977.

56 A. Mickiewicz, Dzieła wszystkie, t. 4: Pan Tadeusz, oprac. K. Górski, Wrocław 1964.

57 J. Kleiner, Studia z zakresu teorii literatury, Lublin 1956.

58 J. Czachowska, Rozwój bibliografii literackiej w Polsce, Wrocław 1979.
} 
przedtytułową zamykał przypis: wraz z fragmentami skreślonymi przez cenzurę na s. 131 i 139. Na tych stronach na marginesach znalazły się własnoręczne dopiski autorki.

\section{5.}

Aby dopełnić wizerunku Hutnikiewicza, nakreślonego w dedykacjach rękopiśmiennych, należy odnieść się do galicyjskich korzeni Profesora, który urodził się w Lwowie i tam zdobył wykształcenie podstawowe, średnie i wyższe. Właśnie do tych szkolnych etapów życia nawiązują dedykacje m.in. Władysławy Lubasiowej czy Jana Bolesława Ożoga ${ }^{59}$, który wspominając naukę w gimnazjum, napisał: Kochanemu Arturowi Hutnikiewiczowi na pamiątkę wspólnie przeżytych lat w VI Gimnazjum Stanistawa Staszica we Lwowie ${ }^{60}$. Do lat studenckich odnosiła się Lubasiowa - Panu Profesorowi Dr. Arturowi Hutnikiewiczowi (gdy ja rozpoczynałam studia polonistyczne na UJK we Lwowie - Pan już je kończyt) Przesytam ten tomik wierszy $Z$ najserdeczniejszymi życzeniami Światecznymi i noworocznymi oraz dla przypomnienia akademickiej znajomości Wtadystawa Lubasiowa (wówczas Wt. Szkaradkówna) [... $]^{61}$. Do tej znajomości Lubasiowa wracała również we wpisie z 1999 roku: Dla przypomnienia Lwowa i Uniwersytetu Jana Kazimierza Arturowi - Wtadysława ${ }^{62}$. Powrót pamięcią do okresu studiów we Lwowie miał na celu również Jan Trzynadlowski, który jako jeden z niewielu pisał dedykacje osobiste: Drogiemu Przyjacielowi Profesorowi Arturowi Hutnikiewiczowi z przypomnieniem lwowskich lat studiów i uściskiem dłoni ${ }^{63}$.

Także Maria Podraza-Kwiatkowaska odwoływała się w swoich dedykacjach do lwowskich spotkań z Profesorem. Pierwszy raz w 1969 roku w Mtodopolskich harmoniach $i d y$ sonansach napisała: Panu Profesorowi [... ] Dla przypomnienia lwowskiego i toruńskiego spotkania - Bardzo serdecznie ${ }^{64}$. Drugi raz lwowską znajomość profesor Podraza-Kwiatkowska przywołała w 1992 roku, przy okazji publikacji Młodej Polski: Panie Profesorze oto Młoda Polska przeze mnie odczytana. Pozwalam sobie ofiarować Panu tę ksiażeczkę z dawna, jeszcze przecież lwowska sympatia $[\ldots]^{65}$. Obok Podrazy-Kwiatkowskiej również profesor Czachowska, nie tylko w Rozwoju bibliografii literackiej, odwoływała się do lwowskiego etapu znajomości. Książkę, napisaną wspólnie z Romanem Lothem - Przewodnik polonisty, opatrzyła w 1975 roku lwowskim pozdrowieniem ${ }^{66}$.

Wyjątkowy cykl stanowią dedykacje Witolda Szolgini ${ }^{67}$, który przygotowując publikacje o historii i kulturze Lwowa, zawsze pamiętal, żeby obdarzyć Hutnikiewicza egzemplarzem z dedykacją autorską. Wpisy te przesiąknięte są dozą sentymentu oraz tęsknoty za Lwowem. Wydawnictwo Szolgini ukazało się pod tytułem Tamten Lwów i zawierało osiem

\footnotetext{
59 Poeta i prozaik, ur. 1913 - zm. 1991. Por. E. Głębicka, Ożóg Jan Bolesław, [hasło w: W Wspótcześni polscy pisarze i badacze literatury. Stownik biobibliograficzny, pod red. J. Czachowskiej i A. Szałagan, t. 6, Warszawa 1999, s. $224-228$.

60 J. Ożóg, Zarys historii Biblioteki Uniwersyteckiej we Wroctawiu, Wrocław 1995.

61 W. Lubasiowa, Cierpki smak jesieni, Nowy Sącz 1995.

62 Eadem, Niektóre wiersze wybrane, Kraków 1999.

63 J. Trzynadlowski, Zakład Narodowy imienia Ossolińskich 1817-1967. Zarys dziejów, Wrocław 1967.

64 M. Podraza-Kwiatkowska, Młodopolskie harmonie i dysonanse, Warszawa 1969.

65 Eadem, Literatura Młodej Polski, Warszawa 1992.

66 J. Czachowska, R. Loth, Przewodnik polonisty, Wrocław 1974.

67 Autor książek o Lwowie, architekt, poeta, ur. 1923-zm. 1996. Por. H. Wiórkiewicz, Witold Szolginia 1923-1996, „Niepodległość i Pamięć” 1966, nr 2 (6), s. 212-217.
} 
tomów, które najpierw sam autor, a później jego żona ofiarowywali Hutnikiewiczowi. W trzecim tomie, poświęconym m.in. lwowskim świątyniom, Szolginia napisał: Panu Profesorowi [...] kolejny tom swego wieloksiagu o naszym rodzinnym Mieście ofiarowuję najserdeczniej ${ }^{68}$. Dedykacje wpisywane do kolejnych woluminów nawiązywały do wspólnego pochodzenia, doświadczeń w wieku dorastania i życia we Lwowie: [...] nieco przypomnień o życiu Naszego Miasta i o naszym życiu w Nim ofiarowuje, jak zawsze najserdeczniej ${ }^{69}$. Szolginia określał Profesora Hutnikiewicza jako tego, „który pamięta”, nie odcina się od wspomnień i przeszłości, ale kultywuje je, żywo pamięta o mieście, które musiał opuścić. Lwowianin w czwartym tomie cyklu napisal: Panu Profesorowi $[. .$.$] ten kolejny tom mego$ lwowskiego "tasiemca" wraz z wyrazami solidarności ludzi wiernie pamiętliwych najserdeczniej ofiarowuję $e^{70}$.

Wyjątkowe więzi, których dowody mamy w dedykacjach, łączyły Hutnikiewicza z ludźmi związanymi z Kresami - m.in. zurodzonymi we Lwowie Skwarczyńską i Trzynadlowskim. Ponadto Skwarczyńska i Hutnikiewicz pracowali w czasie wojny w Instytucie Badań nad Tyfusem Plamistym i Wirusami prof. Rudolfa Weigla ${ }^{71}$. Trzynadlowski - cztery lata starszy od Hutnikiewicza - przez długie lata współpracował z profesor Skwarczyńską m.in. w redakcji „Zagadnień Rodzajów Literackich”72.

\section{6.}

W księgozbiorze są nieliczne publikacje z dedykacjami w osobistym tonie, do których należą m.in. te od lwowskich przyjaciół. Zdecydowana większość wyraża dystans, ogromny szacunek, cześć i podziw. Nieliczni autorzy pozwalali sobie na osobiste, pozbawione patosu, prostolinijne wpisy. Wśród tych osób był m.in. Trzynadlowski, który swoje opracowanie Burmistrza Iwana S. Turgieniewa zadedykował ni mniej ni więcej tylko Arturowi Hutnikiewiczowi ${ }^{73}$, dodając jedynie swój podpis, datę i miejsce. Podobną konstrukcję miała dedykacja wpisana w Babuni ${ }^{74}$, a ewenementem w księgozbiorze, który można zestawić jedynie z dedykacjami od matki czy Zofii - żony Profesora, jest wpis Kochanemu Arturowi $J_{a n e k^{75}}$. Na taką serdeczność w akcie dedykacji pozwolili sobie również Zbigniew Goliński, który podarował Hutnikiewiczowi Pisma Poetyckie Ignacego Krasickiego ${ }^{76}$, oraz Władysław Stabryła, którzy do adresata zwracali się: Drogiemu Arturowi. Te dedykacje pokazują Hutnikiewicza od strony osobistej, prywatnej jako przyjaciela, syna i męża, a szczególne miejsce w części książek z takimi wpisami zajmuje zabrana ze Lwowa pamiątka I komu-

68 W. Szolginia, Tamten Lwów, t. 3: Świątynie, gmachy, pomniki, Wrocław 1993.

69 Idem, Tamten Lwów, t. 5: Życie miasta, Wrocław 1993.

70 Idem, Tamten Lwów, t. 4: My, Lwowianie, Wrocław 1993.

71 Por. A. Szałagan, Skwarczyńska Stefania, [hasło w:] Wspótcześni polscy pisarze i badacze literatury. Stownik biobibliograficzny, pod red. J. Czachowskiej i A. Szałagan, t. 7, Warszawa 2001, s. 309; J. Pitera, Artur Hutnikiewicz, [hasło w: ] ibidem, t. 3, Warszawa 1994, s. 290.

72 Por. M. Kotowska-Kachel, Trzynadlowski Jan, [hasło w: ] ibidem, t. 8, Warszawa 2003, s. 368.

73 I.S. Turgieniew, Burmistrz, oprac. J. Trzynadlowski Wrocław 1952.

74 B. Niemcowa, Babunia, oprac. M.R., Mayenowa, J. Trzynadlowski, Wrocław 1951.

75 Homer, Iliada, oprac. J. Trzynadlowski, Wrocław 1951.

76 I. Krasicki, Pisma poetyckie, t. 1, oprac. Zbigniew Goliński, Warszawa 1976. 
nii świętej - Tajemnice szczęścia Ignacego Marii Loyoli - z dedykacją od matki: Drogiemu Synkowi w dzień Iszej Komunii Św. od Mamy ${ }^{77}$.

Kolejną z osobistych dedykacji jest wpis w książce, którą Profesor otrzymał w prezencie imieninowym w 1949 roku z dedykacją żony: $W$ dniu imienin Arturowi Zosia ${ }^{78}$.

Obraz wyłaniający się z lektury dedykacji rękopiśmiennych, które zgromadził Profesor Hutnikiewicz w swojej bibliotece, przedstawia adresata jako człowieka godnego zaufania, wybitnego naukowca cieszącego się ogromnym szacunkiem, uznaniem i podziwem. Uczniowie nie szczędzili swojemu Mistrzowi serdecznych i miłych słów, składając hołd i wyrażając wdzięczność za lata nauki, pomoc w przygotowaniu dysertacji, ocenie ich w recenzjach. Hutnikiewicz okazywał młodym badaczom wsparcie podczas publikacji, motywował ich do pracy i studiów. Portret dopełnia się w akcie dedykacji, będącym także pretekstem do przywołania lwowskich wspomnień i ukazania Profesora jako lwowianina, pamiętającego o swoich korzeniach. We wpisach znaleźć można także nuty pochwały Hutnikiewicza jako kolegi i przyjaciela.

Jedna z dedykacji, wyjątkowa dla Profesora Hutnikiewicza - co wspomniana profesor Maria Kalinowska - przełamuje pomnikowy wizerunek i pozwala odkryć go jako ambitnego chłopca, wybitnego ucznia, który u początku swojej drogi otrzymał książkę z dedykacją naznaczającą jego przyszłość. Wpis zamieścił Juliusz Balicki w publikacji Będziem Polakami, którą Profesor dostał jako jedenastolatek w nagrodę za udział w konkursie literackim. Ideą tego współzawodnictwa było dopisywanie dalszych ciągów przedwcześnie zakończonych wątków w lekturach szkolnych ${ }^{79}$. Kiedy w 1945 roku Hutnikiewicz w pośpiechu uciekał ze Lwowa, zabrał tę bardzo ważną dla siebie lekturę. Balicki napisał w następujący sposób: Arturowi Hutnikiewiczowi w nagrodę za odznaczone na Konkursie zadanie z życzeniem, by nie ustawat $w$ pracy i szedt coraz wyżej (We Lwowie, dn. 5 września 1928) ( $^{80}$.

77 M. Loyola, Tajemnica szczęścia. Przygotowanie do I-ej Komunji Św., Poznań 1922.

78 E. Orzeszkowa, Cham, Warszawa 1948.

79 A. Hutnikiewicz, O powotaniu nauczyciela - polonisty, „Pomorze” 1960, nr 22, s. 1-2.

80 J. Balicki, S. Maykowski, Będziem Polakami. Drugi rokjęzyka polskiego w szkołach średnich ogólnoksztatcących, Lwów 1928. 


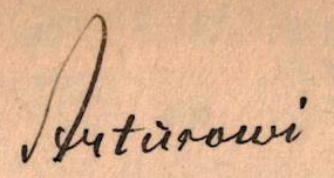

Yicterikieniceoni

w uagrodi $x a$ arenacroce ua Nankiarie radacic.

$x$ èyercisen, by nie totaroat w fracy i nevt coras wepie;

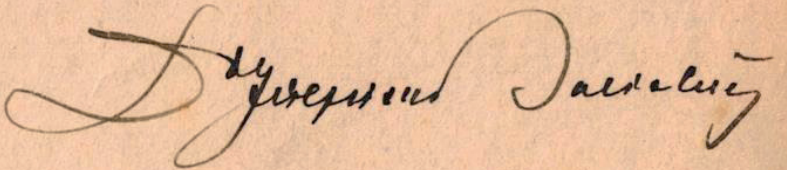

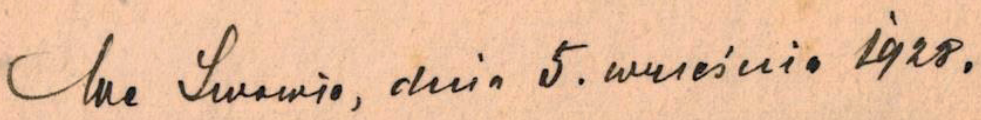


Książka ta dla Hutnikiewicza miała szczególną wartość, a jej autorowi, nauczycielowi gimnazjalnemu, Profesor zawdzięczał - jak sam napisał w liście do Mieczysława Inglota „[..] pierwsze przebudzenie umysłu, zamiłowanie do książek, sztuki, literatury, pierwsze pchnięcie we właściwym kierunku, pierwsze uświadomienie istotnego powołania" ${ }^{\text {. }}$ Profesor cenił talent pedagogiczny Balickiego, a z otrzymaną książką związany był przez całe życie.

Konwencja dedykacji zakłada wyróżnienie i pochwałę adresata, wyrażenie podziękowań i wdzięczności. Z dedykacji rękopiśmiennych w księgozbiorze Profesora wyłania się obraz nakreślony przez studentów, współpracowników, przez osoby bliskie, które pozostawały z Hutnikiewiczem w słabszych lub silniejszych relacjach. Jednak do stworzenia tego obrazu, napisania dedykacji, musiały istnieć realne przesłanki - charyzma Profesora, wiedza, pochodzenie. To one sprawiły, że darczyńcy publikacji w dedykacjach mogli nakreślić wizerunek Profesora Hutnikiewicza - mistrza, czytelnika, lwowianina i przyjaciela.

81 Cyt. za. M. Ingot, Balicki Juliusz Stanisław, [hasło w:] Stownik badaczy literatury polskiej, pod red. J. Starnawskiego, t. 2, Łódź 1998, s. 32. 